\section{Studying Some Properties of Amylases Extracted from 'd'Anjou' Pears}

\author{
S.J. Li, T.J. Facteau, and P. Chen \\ Mid-Columbia Agricultural Research and Extension Center, Oregon State \\ University, Hood River, OR 97031
}

Additional index words. starch, Pyrus communis

\begin{abstract}
Several characteristics of amylases involved in starch degradation were studied in extracts from immature ( 30 days before harvest) 'd'Anjou' pears (Pyrus communis $L$.). Enzyme activity was not detected until after at least 60 minutes of incubation in frozen or lyophilized tissues. Activity increased significantly after 90 minutes and increased linearly after 2 to 12 hours of incubation. Activity was greater, however, in frozen than in lyophilized tissues. Three buffers (acetate, tris-HCl, and imidazole-HCl) were used at a range of $\mathrm{pH}$ levels (4.6-8.2) to ascertain the optimum assay system. Highest specific activity was recorded with acetate buffer at $\mathrm{pH}$ 5.6. The $K_{\mathrm{m}}$ value in this system was $1.43 \times 10^{-3}$ $\mathrm{g} \cdot \mathrm{ml}^{-1}$. Specific activity increased as Ca concentration in the reaction mixture increased from 1 to $15 \mathrm{~mm} \mathrm{CaCl}$ but did not change as Ca concentration increased from 15 to $25 \mathrm{~mm}$ $\mathrm{CaCl}_{2}$. The 'd'Anjou' pear amylases were purified 5.7-fold using ammonium sulfate fractionation.
\end{abstract}

Although various amylases from diverse origins have been purified and their physical and kinetic properties characterized, little is known about these enzymes in fruit. In plants, starch is degraded by at least two enzymesalpha and beta amylases. Chitarra and Lajolo (1981) reported that, in 'Marmelo' bananas (Musa acuminata colla $\times$ Musa balbisiana colla ABB group), in vitro starch degradation had a different temperature coefficient than that of $\alpha$-amylase. This result raised doubts that only $\alpha$-amylase was involved. In maturing apples (Malus domestica Borkh.) and pears, changes in starch concentrations (mainly rated by visible differences after being stained with iodine) are used to determine optimum harvest maturation (Beattie et al., 1972; Kvale, 1986). Li (1991) observed that 'd'Anjou' pears with cork spot, a Ca-related disorder (Raese and Stahly, 1982), have little starch at harvest according to the starch-iodine test. This lack of starch suggests that either decreased starch synthesis or increased starch degradation may be involved in cork spot development.

Our paper reports results of experiments in which amylases in crude protein extracts from immature 'd'Anjou' pears were partially purified and characterized. We did not separate the various enzymes involved in starch degradation, since we were interested in establishing methodologies to investigate starch changes in normal and cork-spotted pears.

Sample preparation, extraction, and enzyme assay. Fruit that seemed normal were

Received for publication 11 Aug. 1992. Accepted for publication 23 Nov. 1992. Oregon State Agricultural Experiment Station technical paper no. 9888. Research supported from funds provided by Hood River Grower Shippers Assn. and the Winter Pear Control Committee. The cost of publishing this paper was defrayed in part by the payment of page charges. Under postal regulations, this paper therefore must be hereby marked advertisement solely to indicate this fact. collected from six mature 'd'Anjou' pear trees at the Mid-Columbia Agricultural Research and Extension Center in Hood River, Ore., on 2 Aug. 1990. Commercial harvest was on 6 Sept. 1990. The fruit were washed in a $0.1 \%$ low-phosphorus detergent solution (LiquiNox, Alconox, New York), rinsed with distilled water, and wiped dry. The calyx half of the fruit was cut into cubes, which were covered quickly with a cloth that had been wetted with $0.5 \%(\mathrm{w} / \mathrm{v})$ sodium metabisulfite solution to minimize oxidative browning. About $40 \mathrm{~g}$ of tissue was sampled from 10 fruit, placed in cheesecloth bags, frozen in liquid nitrogen, and stored at -74C. About $400 \mathrm{~g}$ of frozen tissue was accumulated and bulked for analysis. From the same fruit, a second sample was prepared in the same manner but was lyophilized for 7 days. About $400 \mathrm{~g}$ of tissue was accumulated by thoroughly mixing the ground lyophilized tissue, and all procedures were carried out on this bulked sample at 0 to SC. There were three replicated extractions and analyses for each data point.

Lyophilized tissue (15 g) was homogenized with $7.5 \mathrm{~g}$ insoluble polyvinylpolypyrrolidone and $7.5 \mathrm{~g}$ white quartz sand using a mortar and pestle. Preliminary extractions showed that at least $15 \mathrm{~g}$ dry weight or $100 \mathrm{~g}$ fresh weight of pear tissue was needed to obtain sufficient activity. The sample was ground for $5 \mathrm{~min}$, and then another $10 \mathrm{~min}$ after adding $50 \mathrm{ml}$ of the appropriate extraction buffer (Table 1). The slurry then was squeezed through two layers of Miracloth (CAL Biochem, LaJolla, Calif.), the supernatant was collected in a chilled beaker at $0 \mathrm{C}$, and the residue was reextracted twice more. All supernatants were combined and centrifuged at $5000 \times g$ for $20 \mathrm{~min}$. The clear supernatant (designated as the crude enzyme extract) was transferred to a chilled beaker $(0 \mathrm{C})$, and solid $\left(\mathrm{NH}_{4}\right)_{2} \mathrm{SO}_{4}$ was added to the crude enzyme extract to give specific saturation percentages. The solutions were stirred until the salt was completely dissolved
(40 min) and centrifuged at 10,000x g for 20 min, and the supernatant was discarded. The precipitate was redissolved in $3.0 \mathrm{ml}$ of a solution consisting of the appropriate enzyme buffer (Table 1). The resulting enzyme solution was applied to an Econo-Pat 10 DC column packed with Bio-Gel P-6 desalting gel (Bio-Rad Laboratories, Richmond, Calif.) with a molecular weight exclusion of $\approx 6000 \mathrm{Da}$. The sample was allowed to run into the column after discarding the first $3.0 \mathrm{ml}$ eluted. The higher-molecular-weight components were eluted by adding $4.0 \mathrm{ml}$ of the above buffer and collecting a $4.0-\mathrm{ml}$ fraction from the column into a chilled test tube at $0 \mathrm{C}$. All procedures were exactly the same for the frozen sample, except that the tissue was ground into a powder in a chilled mortar. Based on moisture content, equivalent weights of frozen and lyophilized tissues were extracted.

Amylase activity was assayed by incubating $0.25 \mathrm{ml}$ of the enzyme solution for 2 or 4 $\mathrm{h}$ at $20 \mathrm{C}$ with $0.25 \mathrm{ml}$ of an assay buffersoluble starch $(1 \% \mathrm{w} / \mathrm{v})$ solution (Table 1$)$. The reaction was terminated by adding $0.5 \mathrm{ml}$ dinitrosalicylic acid reagent. The mixture then was diluted 25-fold with distilled water. Optical densities (ODs) were read at $540 \mathrm{~nm}$ using a blank that was prepared with the same amount of enzyme, substrate, and reagent in which the enzyme activity was inactivated immediately in boiling water. $\mathrm{OD}_{540 \mathrm{~mm}}$ values were converted to micromoles of maltose using a standard curve withmaltose (1.0 to $\left.5.0 \mu \mathrm{mol} \cdot \mathrm{ml}^{-1}\right)$. Activity was expressed as micromoles of maltose liberated in $1 \mathrm{~h}$ of reaction at 20C by $1 \mathrm{ml}$ desalted crude extract. Specific activity was expressed as micromoles of maltose per hour per milligram of protein. Total activity was expressed as micromoles of maltose per hour.

Table 1. Extraction, enzyme, assay, and reaction buffer systems and resulting $\mathrm{pH}$ values used to determine activity of 'd'Anjou' pear amylases.

\begin{tabular}{lccc}
\hline \hline \multirow{3}{*}{$\begin{array}{l}\text { Buffer } \\
\text { system }\end{array}$} & \multicolumn{3}{c}{$\mathrm{pH}$} \\
\cline { 2 - 4 } & Tris-HCl & Acetate & Imidazole \\
Extraction $^{z}$ & 7.4 & 5.4 & 7.4 \\
Enzyme $^{y}$ & 7.4 & 5.4 & 7.4 \\
Assay $^{x}$ & 2.1 & 2.8 & 2.0 \\
& 2.2 & 5.4 & 4.0 \\
& 3.0 & 6.0 & 6.0 \\
& 7.4 & & 7.4 \\
& 8.0 & & 9.2 \\
& 9.0 & &
\end{tabular}

$\begin{array}{cccc}\begin{array}{c}\text { Final } \mathrm{pH} \text { of } \\ \text { reaction }\end{array} & & & \\ \text { mixture } & 6.6 & 4.6 & 6.6 \\ & 6.9 & 5.4 & 6.8 \\ & 7.1 & 6.3 & 7.0 \\ & 7.4 & & 7.4 \\ & 7.7 & & 7.9 \\ & 8.2 & & \end{array}$

${ }^{\mathrm{z}} 0.1 \mathrm{M}$ buffer: $5 \mathrm{mM} \mathrm{CaCl}_{2}, 10 \mathrm{~mm}$ mercaptoethanol, $5 \mathrm{~mm}$ ascorbic acid, and $3 \mathrm{mM} \mathrm{Na}_{2} \mathrm{~S}_{2} \mathrm{O}_{5}$.

'Enzyme buffer: $0.1 \mathrm{M}$ buffer and $10 \mathrm{mM}$ mercaptoethanol; refers to the buffer in which the precipitate was dissolved and passed through the desalting column.

${ }^{x}$ Assay buffer: $0.1 \mathrm{~mm}$ buffer and $0.1 \%(\mathrm{w} / \mathrm{v})$ soluble starch; refers to the buffer in which amylase activity was determined. 
Soluble protein in the enzyme preparation was determined by the Bio-Rad (Bio-Rad Laboratories) microassay, using bovine serum albumin as the standard.

Optimum $\mathrm{pH}$ and buffer system. Three buffers were used for each part of the system. This procedure resulted in a range of $\mathrm{pH}$ values for the extraction, enzyme, assay, and final reaction mixture buffer combinations (Table 1). Lyophilized tissue (15 g) was extracted with the buffers as previously described. Final $\mathrm{pH}$ values resulting from the combination of assay and extraction buffers were 4.6 to 6.3 for acetate, 6.6 to 8.2 for tris- $\mathrm{HCl}$, and 6.6 to 7.7 for imidazole-HCl.

Partial purification. Tris- $\mathrm{HCl}$, acetate, and imidazole-HCl buffer systems were used to study the effects of step-wise fractionation with ammonium sulfate. The best buffer combinations found in the $\mathrm{pH}$ buffer system experiment were used. Tris- and imidazole-HCl extraction and assay buffers were $\mathrm{pH}$ 7.4. Acetate extraction and assay buffers were $\mathrm{pH}$ 5.4. Other chemical substances were the same in each buffer (Table 1). Lyophilized tissue $(15 \mathrm{~g})$ was extracted with each of the three buffers as previously described. Solid ammonium sulfate was added to the crude enzyme solution from each buffer to give $30 \%, 65 \%$, or $80 \%$ saturation. The solutions were stirred for 40 min after each $\left(\mathrm{NH}_{4}\right)_{2} \mathrm{SO}_{4}$ addition and centrifuged at $10,000 \times \mathrm{g}$ for $20 \mathrm{~min}$, and the resulting precipitate was saved. These procedures were followed for each $\left(\mathrm{NH}_{4}\right)_{2} \mathrm{SO}_{4}$ fraction. Each precipitate was redissolved with the appropriate buffer and desalted by using an Econo-Pac DC column, as previously described, and amylase activity and protein concentration were determined.

Response to $\mathrm{Ca}$. An acetate extraction buffer was used to study response to increasing $\mathrm{Ca}$ concentration in vitro. Other procedures used in extraction and partial purification were the same as described previously, except that a $65 \%\left(\mathrm{NH}_{4}\right)_{2} \mathrm{SO}_{4}$ precipitated fraction was used. Enzyme solution $(0.25 \mathrm{ml})$ was mixed with $0.25 \mathrm{ml}$ of a soluble starch-sodium acetate buffer ( $\mathrm{pH}$ 5.4) solution that contained $0,8,18$, 28, 38, or $48, \mathrm{~mm} \mathrm{CaCl}_{2}$, so that the final $\mathrm{CaCl}_{2}$ concentration in the reaction mixture was 1 to $25 \mathrm{~mm}$.

Kinetics. An acetate buffer extract from lyophilized tissue $(15 \mathrm{~g})$ was partially purified using the fraction precipitated with $65 \%$ $\left(\mathrm{NH}_{4}\right)_{2} \mathrm{SO}_{4}$. Enzyme solution $(0.25 \mathrm{ml})$ was mixed with $0.25 \mathrm{ml}$ of a soluble starch-sodium acetate buffer ( $\mathrm{pH} 5.4)$ solution in which the soluble starchconcentration was $0.5,1,2,4,6$, 8 , or $10 \mathrm{mg} \cdot \mathrm{ml}^{-1}$.

Time course of amylase activity from 'd'Anjou' pears. Time course measurements on frozen and lyophilized tissues indicated that there was no discernible activity in either tissue until after $60 \mathrm{~min}$ of incubation. Lyophilized tissue released less maltose per milligram protein starting at 90 min incubation for up to $12 \mathrm{~h}$ (Fig. 1A) than frozen tissue. Response was nonlinear from 0 to $120 \mathrm{~min}$, but was linear from 2 to $12 \mathrm{~h}$ (Fig. 1B).

Effect of $p H$ and buffer systems. Optimum enzyme activity occurred at $\mathrm{pH} 5.6$ in acetate
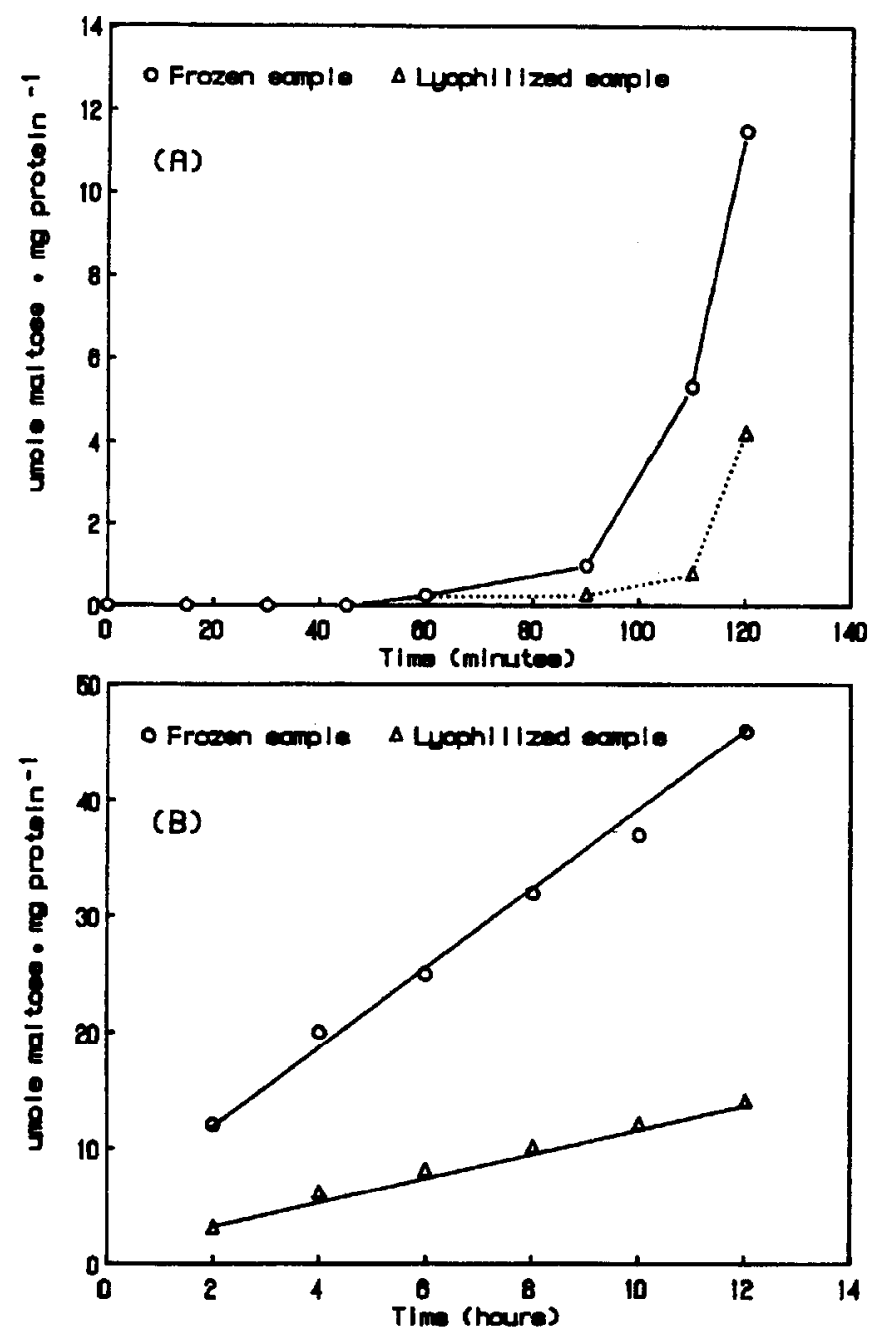

Fig. 1. Time course relationship of maltose production by amylases extracted from fresh and lyophilized 'd'Anjou' pear tissue from (A) 0 to $120 \mathrm{~min}$ and (B) 2 to $12 \mathrm{~h}$. Pears were sampled 2 Aug. 1990, $\approx 30$ days before commercial harvest. and 7.4 in tris- and imidazole-HCl (Fig. 2). Activity was about twice as high in acetate than in tris- $\mathrm{HCl}$.

Partial purification, $\mathrm{Ca}$, and kinetics. The crude enzyme extracts obtained with the three buffer systems were partially purified bypassing the extracts through Bio-Gel P-6 desalting columns followed by step-wise fractionation with $(\mathrm{NH} \& \mathrm{SO}$,. Analysis of variance indicated that there were significant differences between all criteria with respect to buffer, $\left(\mathrm{NH}_{4}\right)_{2} \mathrm{SO}_{4}$ fraction, and their interactive effects (Table 2). Because of the significant interaction and the fact that the experimental

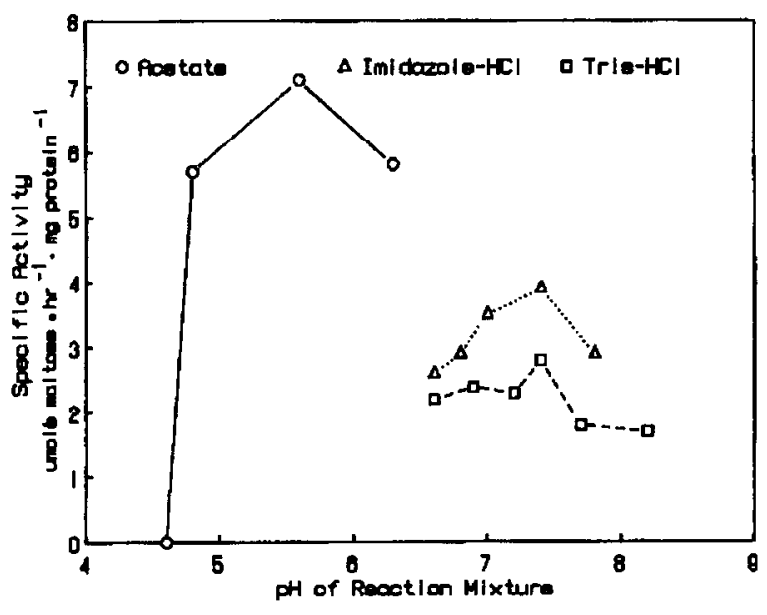

Fig. 2. Interaction of three buffer systems, $\mathrm{pH}$, and specific activity of amylases extracted from 'd'Anjou' pear tissue. See text for details concerning buffers. 
Table 2. Protein concentration, activity, specific activity, total activity, and purification of 'd'Anjou' pear amylases in three buffer systems and four ammonium sulfate fractions.

\begin{tabular}{|c|c|c|c|c|c|c|}
\hline Buffer, pH & $\begin{array}{c}\text { Stage } \\
{[\% \text { saturated }} \\
\left(\mathrm{NH}_{4}\right) \mathrm{SO}_{4} \\
\text { solution] }\end{array}$ & $\begin{array}{l}\text { Protein } \\
\text { dry wt } \\
\left(\mathrm{mg} \cdot \mathrm{g}^{-1}\right)\end{array}$ & $\begin{array}{c}\text { Activity } \\
\text { ( } \mu \text { mol maltose/h } \\
\text { per } 1 \mathrm{ml} \text { desalted } \\
\text { crude extract) }\end{array}$ & $\begin{array}{l}\text { Specific activity } \\
\text { ( } \mu \text { mol maltose/h } \\
\text { per mg protein) }\end{array}$ & $\begin{array}{c}\text { Total } \\
\text { activity } \\
(\mu \mathrm{mol} \\
\text { maltose } / \mathrm{h})\end{array}$ & $\begin{array}{l}\text { Purification } \\
\text { (based on } \\
0 \% \text { to } 80 \% \\
\text { as } 1.00 \text { ) }\end{array}$ \\
\hline \multirow[t]{4}{*}{ Tris-HCl, 7.4} & $0-80$ & $0.19 \mathrm{aA}^{\mathrm{z}}$ & $1.54 \mathrm{aA}$ & $2.14 \mathrm{aA}$ & $6.17 \mathrm{aA}$ & 1.00 \\
\hline & $0-30$ & $0.11 \mathrm{bC}$ & $1.10 \mathrm{bC}$ & $2.69 \mathrm{aA}$ & $4.40 \mathrm{bB}$ & 1.25 \\
\hline & $30-65$ & $0.03 \mathrm{cD}$ & $0.97 \mathrm{bcC}$ & $8.72 \mathrm{bB}$ & $3.87 \mathrm{bcC}$ & 4.18 \\
\hline & $65-80$ & $0.03 \mathrm{cD}$ & $0.77 \mathrm{cD}$ & $7.72 \mathrm{bB}$ & $3.07 \mathrm{cC}$ & 3.60 \\
\hline \multirow[t]{4}{*}{ Acetate, 5.4} & $0-80$ & $0.16 \mathrm{aB}$ & $1.41 \mathrm{aAB}$ & $2.43 \mathrm{aA}$ & $5.65 \mathrm{aAB}$ & 1.00 \\
\hline & $0-30$ & $0.10 \mathrm{bC}$ & $1.23 \mathrm{abBC}$ & $3.20 \mathrm{aA}$ & $4.92 \mathrm{abB}$ & 1.32 \\
\hline & $30-65$ & $0.02 \mathrm{cD}$ & $0.76 \mathrm{bD}$ & $12.91 \mathrm{bC}$ & $4.23 \mathrm{bB}$ & 5.30 \\
\hline & $65-80$ & $0.02 \mathrm{cD}$ & 0.00 & 0.00 & 0.00 & 0.00 \\
\hline \multirow[t]{4}{*}{ Imidazole, 7.4} & $0-80$ & $0.16 \mathrm{aB}$ & $1.35 \mathrm{aB}$ & $2.19 \mathrm{aA}$ & $5.40 \mathrm{aAB}$ & 1.00 \\
\hline & $0-30$ & $0.10 \mathrm{bC}$ & $1.23 \mathrm{aBC}$ & $3.40 \mathrm{bA}$ & $4.91 \mathrm{abB}$ & 1.54 \\
\hline & $30-65$ & $0.03 \mathrm{cD}$ & $1.04 \mathrm{bC}$ & $8.84 \mathrm{cB}$ & $4.29 \mathrm{bB}$ & 4.01 \\
\hline & $65-80$ & $0.02 \mathrm{cD}$ & $0.93 \mathrm{bC}$ & $10.41 \mathrm{dBC}$ & $3.71 \mathrm{cC}$ & 4.07 \\
\hline
\end{tabular}

${ }^{2}$ Means followed by the same lowercase letter were not significantly different at $P=0.05$ within a buffer. Means followed by the same uppercase letter were not significantly different at $P=0.05$ across buffers.

design was a split plot, LSD values were calculated to compare means within buffers (Table 2, lowercase letters) and across buffers (Table 2, uppercase letters). Enzyme activity was highest in the $0 \%$ to $80 \%$ fraction in all buffers. No activity was detected in the $65 \%$ to $80 \%$ $\left(\mathrm{NH}_{4}\right)_{2} \mathrm{SO}_{4}$ fraction from the acetate buffer extraction. The specific activity was highest in the $30 \%$ to $65 \%\left(\mathrm{NH}_{4}\right)_{2} \mathrm{SO}_{4}$ fraction using the acetate buffer. The highest degree of purity was found in the acetate buffer $30 \%$ to $65 \%$ $\left(\mathrm{NH}_{4}\right)_{2} \mathrm{SO}_{4}$ fraction. For all buffers, the $30 \%$ to $65 \%$ and $65 \%$ to $80 \%$ fractions were the most pure. Based on the highest specific activity and degree of purity, the $30 \%$ to $65 \%\left(\mathrm{NH}_{4}\right)_{2} \mathrm{SO}_{4}$ fraction of the acetate buffer extraction system

Table 3. Specific activity of amylases extracted from premature 'd'Anjou' pears at different $\mathrm{Ca}$ concentrations in the reaction mixture.

\begin{tabular}{lc}
\hline $\begin{array}{l}\mathrm{CaCl}_{2} \\
(\mathrm{mM})\end{array}$ & $\begin{array}{c}\text { Specific activity } \\
(\mu \mathrm{mol} \text { maltose/h per mg protein })\end{array}$ \\
\hline 1 & 2.58 \\
5 & 2.88 \\
10 & 5.32 \\
15 & 5.34 \\
20 & 5.32 \\
25 & 5.33 \\
\hline
\end{tabular}

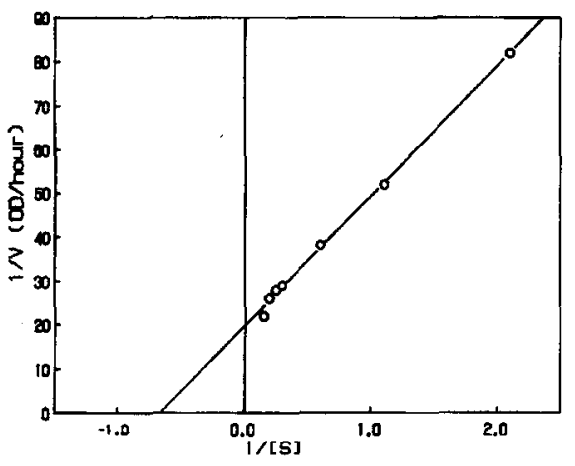

Fig. 3. Lineweaver-Burk plot of soluble starch(s) and amylase activity $(1 / \mathrm{v})$ in 'd'Anjou' pears. Tissue was extracted with acetate buffer and assayed at $\mathrm{pH}$ 5.4. was the most favorable system in 'd'Anjou' pears.

Specific activity increased nonlinearly at $\mathrm{Ca}$ concentrations of 1 to $15 \mathrm{mM} \mathrm{CaCl}_{2}$ in the reaction mixture (Table 3). Because of the rapid increase in specific activity between 5 and $10 \mathrm{mM} \mathrm{CaCl}_{2}$ more data points must be examined to determine a more precise pattern. There was no further change at concentrations of 15 to $25 \mathrm{~mm} \mathrm{CaCl}_{2}$

A Lineweaver-Burk plot (activity as a function of soluble starch concentration) was constructed using starch concentrations of 0.5 to $10 \mathrm{mg} \cdot \mathrm{ml}^{-1}$. As calculated from Fig. $3, \mathrm{~K}_{\mathrm{m}}$ was $1.43 \times 10-{ }^{3} \mathrm{~g} \cdot \mathrm{ml}^{-1}$ with a $\mathrm{V}_{\max }$ of $1.3 \mu \mathrm{mol}$ maltose/h.

Many plant tissues have alpha and beta amylases, but the assay methods used in this study were not specific for either one. Plant $\alpha-$ amylases usually require $\mathrm{Ca}$ for their activity (Okamoto and Akazawa, 1978; Preiss, 1982). We found that enzyme activity was enhanced by $\mathrm{Ca}$. This result suggests that $\alpha$-amylase probably was a constituent of the enzyme complex isolated. The long incubation time and the low $\mathrm{K}_{\mathrm{m}}$ value $\left(1.43 \times 10^{-3} \mathrm{~g} \cdot \mathrm{ml}^{-1}\right)$ showed that the amylases in 'd'Anjou' pears have a low affinity for starch. In comparison, Fan (1975) observed that the $\mathrm{K}_{\mathrm{m}}$ value of 5.45 $\times 10^{-3} \mathrm{~g} \cdot \mathrm{ml}^{-1}$ for potato $\alpha$-amylase was in the high range of values reported for other amylases $\left(0.6 \times 10^{-3}\right.$ to $\left.3.3 \times 10^{-3} \mathrm{~g} \cdot \mathrm{ml}^{-1}\right)$ (Depinto and Campbell, 1968; Manning and Campbell, 1961). The incubation time (>90 min) was similar to that used for determining amylase activity in banana pulp (Chitarra and Lajolo, 1981) but shorter than that used for barley (Hordeum vulgare L.) (Greenwood et al., 1965).

We found that acetate buffer at $\mathrm{pH} 5.4$ gave the highest specific activity compared to the tris- and imidazole- $\mathrm{HCl}$ buffer systems. This result agrees with those of other reports showing that acetate buffers at $\mathrm{pH}$ values of $\approx 5.5$ resulted in maximum activities, mainly of $\alpha-$ amylase, in other crops (Dehaas et al., 1976; Greenwood et al., 1965; Koshiba and Minamikawa, 1981; MacGregor et al., 1974).
Literature Cited

Beattie, B.B., B.L. Wild, and G.G. Coote. 1972. Maturity and acceptability of early picked Granny Smith apples for export. Austral. J. Expt. Agr. Animal Husbandry 12:323-327.

Chitarra, A.B. and F.M. Lajolo. 1981. Phosphorylase, phosphatase, $\alpha$-amylase activity, and starch breakdown during ripening of 'Marmelo' banana [(Musa acuminata Colla) $\times($ Musa balbisiana Colla) AAB group] whole fruit and thin slices. J. Amer. Soc. Hort. Sci. 106:579584 .

Dehaas, B.W., D.W. Chapman, and K.J. Goering. 1976. An investigation of the a-amylase from self-liquefying barley starch. Cereal Chem. 55:127-137.

Depinto, J.A. and L.L. Campbell. 1968. Purification and properties of amylase of Bacillus macerons. Biochemistry 7:114-117.

Fan, M.L. 1975. Purification and properties of potato alpha- $\alpha$-amylase. Tawania 20:71-76.

Greenwood, C.T. and A.W. MacGregor. 1965. The isolation of a-amylase from barley and malted barley, and a study of the properties and actionpatterns of the enzymes. J. Inst. Breweries 71:405-417.

Koshiba, T. and T. Minamikawa. 1981. Purification by affinity chromatography of a-amylase in cotyledons of germinating Vigna mungo seeds. Plant Cell Physiol. 22:979-987.

Kvale, A. 1986. Maturity indexes for pears. Acta Agr. Scandinavia 36:301-304.

Li, S.J. 1991. Determination of a-amylase activity and soluble starch content in normal and cork spotted 'd'Anjou' pear fruit. MS Thesis, Oregon State Univ., Corvallis, Ore.

MacGregor, A.W. and R.G. Thompson. 1974. $\alpha-$ Amylase from immature barley: Purification and properties. J. Inst. Breweries 80:181-187.

Manning, G.B. and L.L. Campbell. 1961. Thermostable alpha-amylase of Bacillus stearothermophillus. I. Crystallization and some general properties. J. Biol. Chem. 236:2952-2957.

Okamoto, K. and T. Akazawa. 1978. Purification of $\alpha-$ and $\beta$-amylase from endosperm tissues of germinating rice seed. Agr. Biochem. 42: 13791384 .

Preiss, J. 1982. Regulation of the biosynthesis and degradation of starch. Annu. Rev. Plant Physiol. 33:431-454.

Raese, T.T. and E.A. Stahly. 1982. Calcium sprays to control physiological disorders of 'd'Anjou' pears. Acta Hort. 124:119-122. 